\title{
Is Islamic Bank More Stable Than Conventional Bank? Evidence From Islamic Rural Banks in Indonesia
}

\author{
Agus Widarjono $^{1}$, M. B. Hendrie Anto ${ }^{1} \&$ Faaza Fakhrunnas ${ }^{1}$ \\ ${ }^{1}$ Department of Economics, Faculty of Business and Economics, University Islam Indonesia, Yogyakarta, Indonesia \\ Correspondence: Agus Widarjono, Department of Economics, Faculty of Business and Economics, University Islam \\ Indonesia, Yogyakarta, Indonesia. Tel: 62-27-488-1546.
}

Received: August 21, 2020

Accepted: November 8, 2020

Online Published: January 14, 2021

doi:10.5430/ijfr.v12n2p294

URL: https://doi.org/10.5430/ijfr.v12n2p294

\begin{abstract}
This study investigates whether Islamic rural banks perform better than conventional rural banks as their competitor in Indonesia. To measure Islamic rural banks' financial performance, we apply financial stability using Z-score and profitability using the return on assets. We use monthly time series data from January 2009 to December 2018. The dynamic regression of the Autoregressive Distributed Lag (ARDL) model is then employed. The results report that the Z-Score of Islamic rural banks is higher than the Z-Score of conventional rural banks. This finding shows that Islamic rural banks are less risky than conventional rural banks. However, the Islamic rural banks' financial stability is very vulnerable to changes in equity, output, and inflation than conventional rural banks. Although the Islamic rural banks' profit rate is lower compared to conventional rural banks, it is considered more stable. The profit of Islamic rural banks is affected by size, equity, domestic output, and inflation.
\end{abstract}

Keywords: Islamic rural bank, financial stability, profitability, Autoregressive Distributed Lag Model, Indonesia

JEL Classification Code: G21, G24, G28

\section{Introduction}

The Islamic financial market is a newcomer to the global financial market. One of the important Islamic financial markets is Islamic banking. The total Islamic financial assets were US\$ 2.44 trillion in 2018, for which Islamic banks, with their asset of US\$ 1.72 trillion, contributed 71\% of the total Islamic financial assets. Iran, Saudi Arabia, Malaysia, UAE, and Qatar are the dominant players of global Islamic banking in the world. Those five countries, with their asset of US\$ 1.34, accounted for $78 \%$ of the world Islamic banking assets. More interestingly, some non-Muslim countries such as the United Kingdom, Luxembourg, Germany, and Russia also practice Islamic banks.

Indonesia, as the biggest Muslim country, has been carrying out Islamic banks since the 1990s. Law No. 7 in 1992 permits a bank to use profit-and-loss sharing principles. The Bank Muamalat Indonesia (BMI) was established in 1992 as the first Islamic bank. Islamic banking grew and expanded quickly as the government issued Islamic banking law no 23 in 2008. There are two types of Islamic banks, which are related to assets and the amount of financing. Large Islamic banks consist of Islamic commercial banks and Islamic bank window in which conventional bank has an Islamic business unit. While small and micro banks consist of Islamic Rural Bank (IRB) and Baitul Mal Wa Tamwil (BMT). There were 31 Islamic commercial banks in 2008 and slightly increase to 34 in 2018. The number of IRB was 132 in 2008, and a bit rose to 165 in 2018, scattering across 27 provinces. However, most IRBs are mainly located on the main island of Indonesia, Java Island, as the most developed regions. Out of the 167 IRB, 103 IRB $(62 \%)$ are located on Java Island.

IRBs play an important role in the Indonesian economy because most Indonesian enterprises are micro, small, and medium enterprises. In 2018, there were 3,694,195 large, medium, small and micro firms consisting of 3,667,873 (99.3\%) small and micro firms and 26,322 (0.7\%) medium and large firms. With a dual banking system in Indonesia, in addition to IRB, Conventional Rural Bank (CRB) also provides funds for micro, small and medium firms. CBR is very dominant and considered as the main competitor of IRB. IRB's assets amounted to IDR 12.36 trillion in 2018, while the total assets of CRB were IDR 135.693 trillion with 1,597 conventional rural banks in 2018. Figure 1 illustrates the trend of ROA between IRB and CRB from January 2011 to December 2018. The profitability of CRB (3.13\%) was higher than the profitability of IRB $(2.50 \%)$. However, the profitability of both banks tends to decline 
recently. Furthermore, an important issue facing IRB is high non-performing financing (NPF). The Indonesian Financial Service Authority, as the regulator, has set up a maximum NPF of 5\%. The average NPF of IRB per month from 2011 to 2018 was $8.53 \%$, while the NPL of CRB was $6.19 \%$. Thus, IRB is very vulnerable to facing bankruptcy.

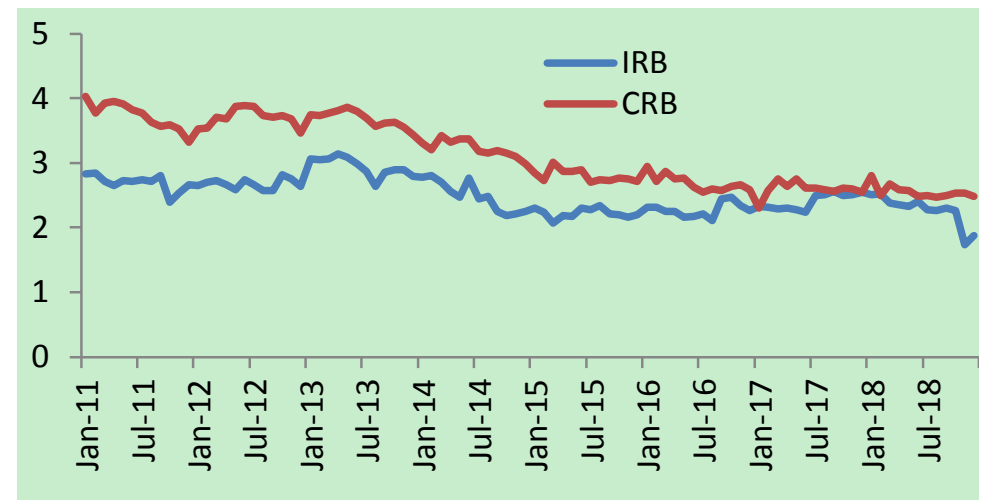

Figure 1. ROA 2011: M1 to 2018:M6

Islamic bank provides a different financial contract from a conventional bank. Instead of interest rate as the fixed cost, the Islamic bank offers profit-and-loss sharing (PLS) and non-profit-and-loss sharing (non- PLS) contract. Similar to the Islamic commercial bank, the IRB as a financial intermediary provides a saving deposit as well as financing. On the financing side, IRB offers two types of financing schemes comprising profit-and-loss sharing (PLS) and non-PLS. On the one hand, the PLS contract is a financing contract where profits and losses are shared with both parties, such as mudharaba and musyaraka. On the other hand, Non-PLS is a financing contract based on sales principles such as cost-plus (murabaha), leasing (Ijara), forward contract (Salam), manufacturing contract (Istishna), benevolence (Qard), and Multi-purpose financing. In terms of the deposits side, IRB offers demand deposits and saving deposits. Both deposits are based on either the wadiah or mudharaba contract. Wadiah contract is a contract between a depositor and an Islamic bank for safekeeping. The important issue is whether these Islamic financial contracts lead to a better financial performance of Islamic rural banks than conventional rural banks.

This paper investigates the Islamic banks' financial stability and compares them to conventional banks for Indonesian Islamic rural banks as small Islamic banks. Researches on the financial performance of Islamic bank have investigated on large Islamic banks such as Mirza et al. (2015) for Pakistan, Lassoued (2018) for Malaysia, Sutrisno and Widarjono (2018) for Indonesia, Hassan et al. (2019) from selected Organization of Islamic Cooperation Countries among the others. Furthermore, several studies also compared the financial performance of the Islamic bank and the conventional bank, but the results are unclear. Some existing empirical studies document that Islamic banks have better financial performance than conventional banks, such as Alqahtani et al. (2016), Miah and Uddin (2017), Hussien et al. (2019), and Hassan et al. (2019). By contrast, the conventional bank has better financial performance than Islamic banks such as Kabir et al. (2015), Zins and Weill (2017), and Lassoued (2018). There are a few empirical studies related to small Islamic banks. Warninda (2014), Trinugroho et al. (2017), and Widarjono et al. (2020) addressed profitability. Trinugroho et al. (2018) examined bank margin, and Widarjono, Anto and Fakhrunnas, (2020) investigated financing risk. Therefore, it is expected that this present study contributes to the empirical literature on the financial performance of small Islamic banks.

The rest of the paper is arranged as follows. Section 2 discusses the highlights of previous empirical researches on the financial stability of Islamic banks. The next section discusses the method and data to investigate the financial stability of IRB. This study employs the ARDL method to address this issue using monthly time series data. The findings of this research are presented and discussed in section 4. The last section summarizes the conclusion, including policy recommendations regarding IRB in Indonesia.

\section{Review Literature}

Many previous studies investigated the financial stability of Islamic banks. The stability of an Islamic bank is affected by both Islamic bank characteristics and macro variables. Ghenimi et al. (2017) reported that Islamic bank 
stability is influenced by income diversity, liquidity, credit risk, ROA, Size, CAR, and inflation. Trad et al. (2017) found that size and capital are the main factors of Islamic banks' stability. Besides, the GDP and exchange rate variables can improve the stability of Islamic banks. Srairi (2019) identified that size, efficiency, deposit rates, asset growth, GDP growth, risk depth, and credit information concentration determine Islamic financial stability. More interestingly, increasing transparency in Islamic banks is a key indicator of the stability of the bank.

Some empirical studies also investigated financial stability between large and small Islamic banks. Based on Z-score, Čihák and Hesse (2010) and Abedifar et al. (2013) reported that large Islamic bank is financially weaker than small Islamic bank due to lower credit risk in a small Islamic bank. By contrast, several studies showed that small Islamic bank is riskier than large Islamic bank. Using their market forces, large Islamic banks have better stability because it has a greater ability in reducing credit risk than small Islamic banks (Kabir and Worthington, 2017; Ibrahim and Rizvi, 2017)

With its financing contracts that are different from a conventional bank, an Islamic bank is prohibited from using interest rates in their transactions. Instead, Islamic banks operate based on shariah compliance principles, which consist of profit-and-loss sharing (PLS) and non-PLS in providing funds to customers. PLS consists of mudharaba and musyaraka while non-PLS consists of murabaha, Salam, istishna, and ijarah. The question is whether these different contract schemes could lead Islamic banks to be less risky than conventional banks on their financial performance.

The previous empirical researches on financial stability between Islamic banks and conventional banks have resulted in mixed findings. Several factors make an Islamic bank better than a conventional bank. First, because of the relatively limited investment products that comply with Shariah principles, an Islamic bank under the Islamic principles holds greater liquidity than a conventional bank (Hussein, 2010; Waemustafa and Sukri, 2016). Second, an Islamic bank has better risk management (Alaro and Hakeem, 2011; Baele et al., 2014; Alqahtani et al., 2016; Hassan et al., 2019). Third, an Islamic bank is less influenced by any shock because Islamic bank is banned from any speculative business as well as excessive financing which cause the recent world financial crisis (Parashar and Venkatesh, 2010; Abdulle and Kassim, 2012; Beck et al., 2013; Rahim and Zakaria, 2013; Miah and Uddin, 2017; Hussien et al., 2019).

However, some previous studies documented that conventional banks have better financial stability than Islamic banks. Financing with a profit-sharing system such as mudharaba and musyaraka creates agency problems such as asymmetric information, a moral hazard that causes greater credit risk. Kabir et al. (2015) reported that the Islamic bank has a lower $\mathrm{Z}$ score and higher NPL than a conventional bank. Therefore, the Islamic bank has higher credit risk. Lassoued (2018) found that Islamic banks in Malaysia were more vulnerable to financing risk and bankruptcy and had a lower level of stability compared to conventional banks. Miniaoui and Gohou (2013) for the UAE case also indicated that the Islamic bank performs worse than the conventional bank. Zins and Weill (2017) documented that due to the special product of Islamic banks, profit-and-loss sharing schemes, and transparency contracts, Basel II increased the bankruptcy of Islamic banks.

\section{Methods and Data}

This present study follows previous studies such as Čihák and Hesse (2010), Abedifar et al. (2013), Beck et al. (2013), Lassoued (2018), Hassan et al. (2019), and Widarjono et al. (2020) among the others. This study includes both IRB's characteristics and macroeconomic variables. ARDL is applied to analyze the financial stability of IRB. Because Z-Score relies on the probability rate, this study also investigates the IRB's profitability to check the model's robustness. The financial stability and profitability model can be written in the following regression equation:

$$
Y_{t}=\beta_{0}+\beta_{1} \text { LASSET }_{t}+\beta_{2} \text { GFIN }_{t}+\beta_{3} \text { CAR }_{t}+\beta_{4} \text { NFP }_{t}+\beta_{5} \text { IPI }_{t}+\beta_{6} \text { CPI }_{t}+\beta_{7} \mathrm{LEXC}_{t}+e_{t}
$$

Where $\mathrm{Y}$ is $\mathrm{Z}$-score or ROA.

Z-score is applied to measure the financial stability of IRB following the previous empirical studies such as Čihák and Hesse (2010), Abedifar et al. (2013), Zins and Weill (2017) Hassan et al. (2019) among the others. Z-Score is calculated using $(R O A+C A R) / S D(R O A)$ and $\mathrm{SD}$ is a standard deviation. A high Z-Score represents a lower probability of bankruptcy and vice versa. Return on asset (ROA) is a proxy of profitability (Masood and Ashraf, 2012; Warninda, 2014). The IRB's financial stability and profitability are affected by both bank characteristics as well as macroeconomic variables. The Islamic rural bank characteristics consist of assets, growth of financing, Capital Adequacy Ratio (CAR), and Non-Performing Financing (NPF). The macroeconomic variables are output, which is measured by industrial production index (IPI) due to lack of monthly GDP data, Inflation (CPI), and exchange rate $(\mathrm{EXC})$. 
An asset that measures the Islamic banks' size represents the high power to create revenue, so it is expected to positively link stability and profitability. CAR represents the bank's ability to hold its capital. High CAR means that an Islamic bank can expand its business to create more profit. We expect that CAR positively affect profitability. The FDR indicates the Islamic bank's ability to provide the fund to the public in terms of financing. The high financing leads to a bank to create higher profit. We expect FDR has a positive effect on profit. The OER, which is a ratio of operating expense to operating revenue, measures the efficiency of an Islamic bank. Higher OER is lower efficiency so we expect that OER negatively links to profit. NPF is bad financing of Islamic banks. Higher NFP shows higher bad financing so it lowers Islamic banks to create profit. We include macroeconomic variables to describe the change in the business cycle. High economic growth is related to good economic conditions so we expect a positive relationship between economic growth and Islam bank profitability. By contrast, high inflation negatively affects profit. Indonesia relies on imported input so the domestic economy, including Islamic banks, is affected by domestic currency change. Depreciation of domestic currency worsens the domestic economy and vice versa. It is expected to link a negative relationship between the exchange rate and profitability of the Islamic bank. Table 1 reports the variable definition and the expected sign of independent variables.

Table 1. Variable definition and expected sign

\begin{tabular}{lll}
\hline Variable & definition & Expected sign \\
\hline Dependent variable & & \\
\hline Z-Score & (ROA+CAR)/ Standard deviation of ROA & \\
\hline ROA & Returns on Asset & + \\
\hline Independent variable & & + \\
\hline Bank Characteristics & & + \\
\hline ASSET & Total Asset (IDR billion). & - \\
\hline GFIN & Growth of financing (\%). & + \\
\hline CAR & Equity over total assets (\%). & - \\
\hline NPF & Non Performing financing (\%). & + \\
\hline Macro variables & & \\
\hline IPI & Industrial Production index as a proxy for output & + \\
\hline CPI & Inflation (\%). It measures the general level of consumer price & - \\
\hline EXC & A monthly average of the Indonesia Rupiah (IDR) against the US & - \\
\hline
\end{tabular}

The ARDL model of equation (1) is as follows:

$$
\begin{array}{r}
\Delta \mathrm{Y}_{\mathrm{t}}=\theta_{0}+\theta_{1} \mathrm{Y}_{\mathrm{t}-1}+\theta_{2} \mathrm{LASSET}_{\mathrm{t}-1}+\theta_{3} \operatorname{GFIN~}_{\mathrm{t}-1}+\theta_{4} \mathrm{CAR}_{\mathrm{t}-1}+\theta_{5} \operatorname{NPF}_{\mathrm{t}-1}+\theta_{6} \operatorname{IPI}_{\mathrm{t}-1}+\theta_{7} \operatorname{CPI}_{\mathrm{t}-1}+\theta_{8} \mathrm{LEXC}_{\mathrm{t}-1}+ \\
\sum_{\mathrm{i}=1}^{\mathrm{n}} \varphi_{1 \mathrm{i}} \Delta \mathrm{Y}_{\mathrm{t}-1}+\sum_{\mathrm{i}=1}^{\mathrm{n}} \varphi_{2 \mathrm{i}} \Delta \mathrm{LASSET}_{\mathrm{t}-1}+\sum_{\mathrm{i}=1}^{\mathrm{n}} \varphi_{3 \mathrm{i}} \Delta \mathrm{GFIN}_{\mathrm{t}-1}+\sum_{\mathrm{i}=1}^{\mathrm{n}} \varphi_{4 \mathrm{i}} \Delta \mathrm{CAR}_{\mathrm{t}-1}+\sum_{\mathrm{i}=1}^{\mathrm{n}} \varphi_{5 \mathrm{i}} \Delta \mathrm{NPF}_{\mathrm{t}-1} \\
\sum_{\mathrm{i}=1}^{\mathrm{n}} \varphi_{6 \mathrm{i}} \Delta \mathrm{IPI}_{\mathrm{t}-1}+\sum_{\mathrm{i}=1}^{\mathrm{n}} \varphi_{7 \mathrm{i}} \Delta \mathrm{CPI}_{\mathrm{t}-1}+\sum_{\mathrm{i}=1}^{\mathrm{n}} \varphi_{8 \mathrm{i}} \Delta \mathrm{LEXC}_{\mathrm{t}-1}+\mu_{\mathrm{t}}
\end{array}
$$

$\theta_{1}$ to $\theta_{8}$ indicate the long-run relationship of the model and the rest of them $\left(\varphi_{1 i}-\varphi_{8 i}\right)$ show the short-run relationship of the model.

The steps to estimate the ARDL starts with a stationary test to examine the equilibrium condition of variables. Augmented Dickey-Fuller (ADF) and Phillips-Perron (PP) using both constant and constant and trend are applied. The second step checks the presence of a long-run relationship between variables employing the bound testing approach (Pesaran et al., 2001). The null hypotheses of no cointegration are as follows:

$$
\mathrm{H}_{0}: \theta_{1}=\theta_{2}=\theta_{3}=\theta_{4}=\theta_{5}=\theta_{6}=\theta_{7}=\theta_{8}=0
$$

The Bound testing test follows the F statistic distribution. The critical F values are based on Pesaran et al. (2001). The cointegration exists as the computed $\mathrm{F}$ value is greater than the upper bound $\mathrm{I}(1)$. However, as the computed $\mathrm{F}$ value is smaller than the lower bound $\mathrm{I}(0)$, cointegration does not present. The cointegration is not clear as the computed $\mathrm{F}$ value between the lower bound $\mathrm{I}(0)$ and the upper bound $\mathrm{I}(1)$. 
Because there is a competition between Islamic and conventional rural banks, this study also includes a comparison of financial stability between Islamic and conventional rural banks. The financial data of IRB and CRB are aggregate data of all banks. Monthly time series data from January 2009 to December 2018 are applied. All financial data of Islamic and conventional rural banks are obtained from the Indonesian Financial Services Authority. Industrial production index (IPI) and Consumer Price Index (CPI) are taken from The Indonesian Bureau Central of Statistics. Exchange rate data are from the International Financial Statistics.

\section{Results and Discussion}

Table 2 represents the descriptive statistics for both IRB and CRB. IRB's Z-Score is higher than the CRB's Z-Score but IRB's Z-Score is more volatile because of its higher standard deviation than CRB as its counterpart. The higher Z-Score of IRB is due to two things which are from more stable ROA and higher CAR compared to CRB. The standard deviation of the CRB's ROA (1.399) is three times the standard deviation of the IRB (0.448). IRB's ROA is more stable due to better risk management because Islamic banks are prohibited from conducting speculative financing (gimar) and gambling (gharar) (Hassan et al., 2019). This finding is in line with previous findings in Rahim and Zakaria (2013) which took place in Malaysia during 2005-2015 and Čihák and Hesse (2010) in 19 countries during the period of 1993-2004. However, this finding contradicts the previous findings where IRB's Z-score was lower than that of CRB such as Beck et al. (2013), Zins and Weill (2017), Hassan et al. (2019). A higher Z score indicates that the IRB is less risky with a lower probability of default than CRB. Even so, IRB's Z-score tends to decrease while the Z-Score of the CRB is relatively stable, see figure 3. The decrease in Z-score was due to the decline in the profitability of IRB since 2014. The average RAO was $2.99 \%$ from 2009 to 2013 and was $2.33 \%$ from 2014 to 2018.

Whereas, based on profitability, CRB's ROA is higher than IRB's ROA but with a higher variation. One of the main factors which lead to a low ROA of IRB is because of a new player in the banking system for micro, small and medium enterprises. IRB could not compete with CRB. However, as a new Islamic bank, the IRB's financing growth was higher than the CRB's loan growth. IRB's CAR is also higher than its CAR counterpart but with a higher standard deviation. Non-performing financing (NPF) of IRB is higher than the non-performing loan (NPL) of CRB. This condition happens because the financing of IRB based on a PLS contract often causes agency problems such as asymmetric information and moral hazard (Azmat et al., 2015; Widarjono et al., 2020). The NPF of PLS contracts were $76 \%$ while those of non-PLS contracts were only $24 \%$ in 2018.

Table 2. Descriptive statistics for variables

\begin{tabular}{lccrr}
\hline & Mean & Maximum & Minimum & Std. Dev. \\
\hline Z-ScoreIRB (\%) & 41.694 & 53.432 & 34.307 & 4.850 \\
\hline Z-ScoreCRB (\%) & 12.633 & 15.881 & 8.912 & 0.756 \\
\hline ROAIRB (\%) & 2.657 & 3.970 & 1.730 & 0.448 \\
\hline ROACRB (\%) & 3.029 & 4.030 & -9.740 & 1.399 \\
\hline ASSETIRB (IDR billion) & 5,999 & 12,362 & 1,702 & 3,096 \\
\hline ASSETCRB (IDR billion) & 79,439 & 135,693 & 32,681 & 31,559 \\
\hline GFINIRB (\%) & 0.017 & 0.051 & -0.009 & 0.013 \\
\hline GFINCRB (\%) & 0.012 & 0.026 & -0.021 & 0.009 \\
\hline CARIRB (\%) & 16.030 & 20.490 & 13.370 & 1.839 \\
\hline CARCRB (\%) & 14.534 & 19.320 & 13.100 & 0.904 \\
\hline NPFIRB (\%) & 8.535 & 11.800 & 6.150 & 1.577 \\
\hline NPLCRB (\%) & 6.194 & 10.320 & 4.410 & 0.905 \\
\hline IPI (\%) & 118.219 & 148.050 & 92.320 & 15.576 \\
\hline CPI (\%) & 110.382 & 135.390 & 85.720 & 15.811 \\
\hline EXC (IDR) & 11,430 & 15,179 & 8,527 & 2,022 \\
\hline
\end{tabular}




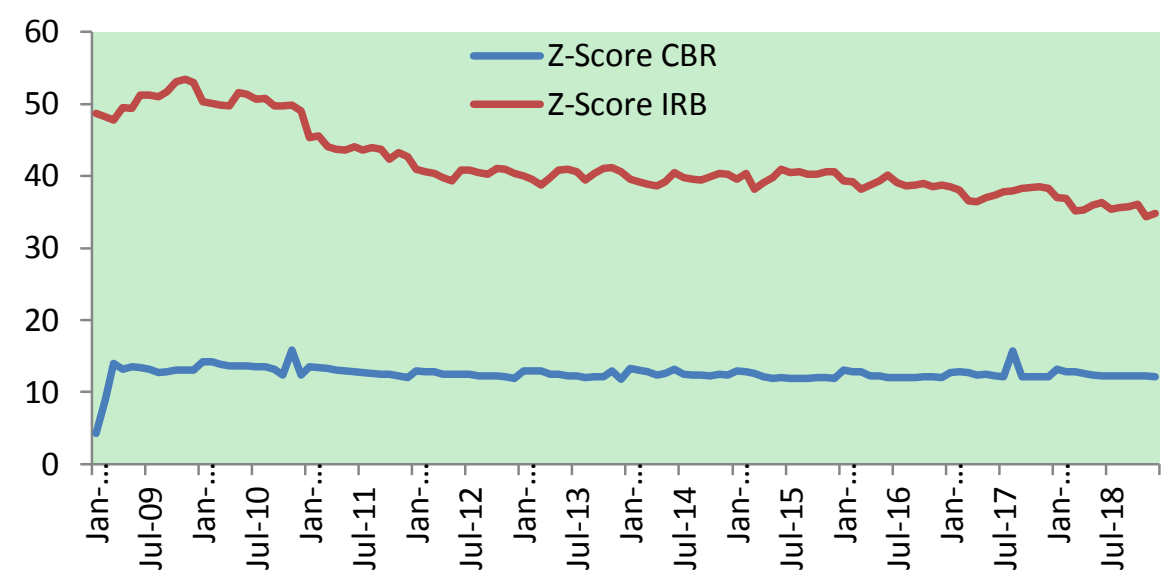

Figure 2. Z-Score 2009:M1 - 2018:M12

Before estimating the ARDL model, this study checks stationarity data, including constant and constant and trend. ADF and PP tests which are shown in Table 5, report that several data such as CRB's Z-score, CRB's ROA, IRB's asset, IRB's gfin, IRB's CAR, CRB's CAR, CRB's NPL, and Exc are stationary at level data and the rest of them are stationary at the first difference level data. All data are stationary at the data difference level. The stationarity test results confirm that the ARDL model is the appropriate model in estimating the financial performance of IRB as well as CRB.

Table 3. Stationary test

\begin{tabular}{|c|c|c|c|c|c|c|c|c|}
\hline & \multicolumn{4}{|l|}{ Level Data } & \multicolumn{4}{|c|}{ Difference data } \\
\hline & $\mathrm{ADF}$ & & PP & & $\mathrm{ADF}$ & & PP & \\
\hline & $\mathrm{C}$ & $C \& T$ & $\mathrm{C}$ & $C \& T$ & $\mathrm{C}$ & $C \& T$ & $\mathrm{C}$ & $C \& T$ \\
\hline Z-IRB & -1.83 & $-4.00^{* * *}$ & -1.75 & $-5.84 * * *$ & $-15.65 * * *$ & $-15.58 * * *$ & $-25.81 * * *$ & $-26.89 * * *$ \\
\hline Z-CRB & $-9.43 * * *$ & $-11.44 * * *$ & $-10.78 * * *$ & $-13.01 * * *$ & $-9.59 * * *$ & $-9.52 * * *$ & $-16.82 * * *$ & $-16.86^{* * *}$ \\
\hline ROA_IRB & -1.60 & -3.11 & -1.37 & -3.03 & $-12.83 * * *$ & $-12.85 * * *$ & $-12.85 * * *$ & $-12.85 * * *$ \\
\hline ROA_CRB & $-9.55 * * *$ & -3.14 & $-12.54 * * *$ & $-24.84 * * *$ & $-10.52 * * *$ & $-10.25 * * *$ & $-43.50 * * *$ & $-43.32 * * *$ \\
\hline Lasset_IRB & $-3.32 * *$ & -0.69 & $-3.37 * *$ & -0.68 & $-10.71 * * *$ & $-11.95 * * *$ & $-10.96 * * *$ & $-10.96 * * *$ \\
\hline LAseet_CRB & -2.49 & -0.97 & -2.77 & -2.84 & $-13.04 * * *$ & $-10.23 * * *$ & $-25.20 * * *$ & $-43.83 * * *$ \\
\hline Gfin_IRB & $-7.15 * * *$ & $-7.90 * * *$ & $-7.15 * * *$ & $-7.65 * * *$ & $-11.19 * * *$ & $-11.12 * * *$ & $-42.16^{* * *}$ & $-42.76 * * *$ \\
\hline Gfin_CRB & -0.66 & $-3.99 * *$ & $-8.16 * * *$ & $-8.65 * * *$ & $-9.02 * * *$ & $-9.17 * * *$ & $-19.53 * * *$ & $-19.48 * * *$ \\
\hline CAR_IRB & -2.04 & $-4.17 * * *$ & -2.03 & $-6.10 * * *$ & $-15.79 * * *$ & $-15.72 * * *$ & $-29.79 * * *$ & $-31.90 * * *$ \\
\hline CAR_CRB & $-4.60 * * *$ & $-4.57 * * *$ & $-7.94 * * *$ & $-7.94 * * *$ & $-8.74 * * *$ & $-8.73 * * *$ & $-51.91 * * *$ & $-64.82 * * *$ \\
\hline NPF_IRB & -0.25 & -2.55 & -1.41 & $-3.25^{*}$ & $-2.88^{*}$ & -2.76 & $-13.86^{* * *}$ & $-14.00 * * *$ \\
\hline NPL_CRB & -0.97 & -1.67 & $-4.64 * *$ & $-4.43 * *$ & $-3.01 * *$ & $-3.15 * * *$ & $-12.44 * * *$ & $-13.21 * * *$ \\
\hline IPI & -0.44 & -9.07 & -0.72 & -9.08 & $-13.35 * * *$ & $-13.29 * * *$ & $-53.94 * * *$ & $-54.96 * * *$ \\
\hline $\mathrm{CPI}$ & -0.28 & -2.00 & -0.01 & -2.48 & $-9.91 * * *$ & $-9.87 * * *$ & $-7.26 * * *$ & $-7.20 * * *$ \\
\hline LEXC & -0.31 & $-4.51 * * *$ & -0.16 & -3.00 & $-7.91 * * *$ & $-8.25 * * *$ & $-8.18 * * *$ & $-8.37 * * *$ \\
\hline
\end{tabular}

Note: $* * * ; * ; *$ are stationer at $\alpha=1 \%, 5 \%$ and $10 \%$ respectively. $\mathrm{C}=$ constant; $\mathrm{T}=$ trend 
This study employs the AIC method to come up with the optimum lag which is up to 6 lag orders. The selected Z-score model is $\operatorname{ARDL}(2,0,1,1,0,5,0,0)$ for IRB and ARDL $(5,4,0,6,4,0,0,4)$ for CRB. Meanwhile the selected RAO model is $(1,0,1,2,0,4,0,0)$ for IRB and ARDL $(4,4,0,0,4,0,1,1)$ for CRB. Table 3 presents the ARDL estimation for both IRB as well as CRB. The top panel and the bottom panel of Table 2 are ARDL estimation and diagnostic tests of OLS assumptions, respectively. The Jerque-Berra (JB) is the test for normality of residuals, Autoregressive Conditional Heteroskedasticity (ARCH) is the test for heteroskedasticity, and Lagrange Multiplier (LM) is the test for autocorrelation. Except for normality, the results pass the absence of autocorrelation and heteroskedasticity. The stability test through CUSUM and CUSUM of squares presented in Figure 3 - 6 shows ARDL leads to the regression coefficient's stability. The results of the diagnostic test demonstrate that the ARDL model suits the OLS assumption. Out of 16 independent variables in the Z-Score model, ten variables are statistically significant at $\alpha=10 \%$ or less for IRB, meanwhile 19 out of 32 independent variables are statistically significant at $\alpha$ $=10 \%$ or less for CRB. In the ROA model, 8 out of 17 independent variables are statistically significant at $\alpha=10 \%$ or less for IRB and 13 out of 21 independent variables are statistically significant at $\alpha=10 \%$ or less for CRB.

Table 4. ARDL estimation

\begin{tabular}{|c|c|c|c|c|c|c|c|c|}
\hline & Z-Score IRB & & Z-Score CRB & & ROA IRB & & ROA CRB & \\
\hline & Coeff. & s.e & Coeff. & s.e & Coeff. & & Coeff. & s.e \\
\hline$C$ & -21.328 & 17.511 & 5.597 & 4.426 & $-16.984 * *$ & 8.042 & $8.345^{*}$ & 5.580 \\
\hline$y_{t-1}$ & $0.669 * * *$ & 0.069 & $0.652 * * *$ & 0.104 & $0.761 * * *$ & 0.055 & $0.686^{* * *}$ & 0.105 \\
\hline$y_{t-2}$ & $0.082 * *$ & 0.045 & $0.190 * *$ & 0.114 & & & 0.029 & 0.100 \\
\hline$y_{t-3}$ & & & $-0.157 *$ & 0.104 & & & $-0.138^{*}$ & 0.051 \\
\hline$y_{t-4}$ & & & $-0.203^{*}$ & 0.092 & & & 0.042 & 0.028 \\
\hline$y_{t-5}$ & & & 0.028 & 0.020 & & & & \\
\hline Lasset $_{t}$ & 1.082 & 1.309 & -0.119 & 0.365 & & & 0.169 & 0.526 \\
\hline Lasset $_{t-1}$ & & & 0.350 & 0.356 & $1.188^{* *}$ & 0.590 & $0.814 * *$ & 0.408 \\
\hline Lasset $_{t-2}$ & & & $-1.103 * * *$ & 0.343 & & & $-1.787 * * *$ & 0.414 \\
\hline Lasset $_{t-3}$ & & & 0.438 & 0.378 & & & 0.509 & 0.471 \\
\hline Lasset $_{t-4}$ & & & $0.543^{*}$ & 0.338 & & & 0.289 & 0.426 \\
\hline G fin $_{t}$ & $-5.338 * *$ & 3.312 & 0.854 & 1.486 & -1.952 & 1.595 & $3.445 * *$ & 1.925 \\
\hline $\operatorname{Gfin}_{t-1}$ & $5.504 *$ & 3.262 & & & $3.297 * *$ & 1.629 & & \\
\hline$C A R_{t}$ & $2.480 * * *$ & 0.114 & $0.719 * * *$ & 0.014 & $0.130 * *$ & 0.055 & 0.015 & 0.021 \\
\hline$C A R_{t-1}$ & $-1.827 * * *$ & 0.203 & $-0.462 * * *$ & 0.077 & $-0.167 * *$ & 0.080 & & \\
\hline$C A R_{t-2}$ & & & $-0.122 *$ & 0.084 & $0.146^{* *}$ & 0.059 & & \\
\hline$C A R_{t-3}$ & & & $0.118^{*}$ & 0.075 & & & & \\
\hline$C A R_{t-4}$ & & & $0.152 * *$ & 0.068 & & & & \\
\hline$C A R_{t-5}$ & & & -0.018 & 0.019 & & & & \\
\hline$C A R_{t-6}$ & & & $-0.016^{*}$ & 0.012 & & & & \\
\hline$N P F_{t}$ & 0.038 & 0.064 & $0.072 * *$ & 0.039 & 0.024 & 0.029 & 0.044 & 0.055 \\
\hline$N P F_{t-1}$ & & & $-0.137 * * *$ & 0.049 & & & $-0.171 * *$ & 0.071 \\
\hline$N P F_{t-2}$ & & & 0.027 & 0.049 & & & $0.130^{* *}$ & 0.062 \\
\hline$N P F_{t-3}$ & & & $-0.119 * * *$ & 0.045 & & & $-0.183 * * *$ & 0.056 \\
\hline$N P F_{t-4}$ & & & $0.104 * *$ & 0.043 & & & $0.110^{* * *}$ & 0.052 \\
\hline$N P F_{t-5}$ & 0.002 & 0.010 & & & 0.000 & 0.005 & $0.008 * *$ & 0.004 \\
\hline
\end{tabular}




\begin{tabular}{|c|c|c|c|c|c|c|c|c|}
\hline & \multicolumn{2}{|l|}{ Z-Score IRB } & \multicolumn{2}{|l|}{ Z-Score CRB } & \multirow{2}{*}{$\begin{array}{c}\text { ROA IRB } \\
\text { Coeff. }\end{array}$} & \multicolumn{3}{|c|}{ ROA CRB } \\
\hline & Coeff. & s.e & Coeff. & s.e & & & Coeff. & s.e \\
\hline$I P I_{t-1}$ & -0.009 & 0.010 & $0.009 * * *$ & 0.003 & -0.004 & 0.005 & & \\
\hline$I P I_{t-2}$ & 0.012 & 0.010 & & & 0.006 & 0.005 & & \\
\hline$I P I_{t-3}$ & 0.007 & 0.010 & & & 0.002 & 0.005 & & \\
\hline$I P I_{t-4}$ & $0.028^{* * * *}$ & 0.010 & & & $0.012^{* *}$ & 0.005 & & \\
\hline$I P I_{t-5}$ & $0.016^{*}$ & 0.010 & & & & & & \\
\hline$C P I_{t}$ & $-0.113 * * *$ & 0.039 & $-0.016^{*}$ & 0.010 & $-0.055 * * *$ & 0.018 & $-0.036^{*}$ & 0.023 \\
\hline$C P I_{t-1}$ & & & & & & & 0.026 & 0.026 \\
\hline $\operatorname{Lexc}_{t}$ & $1.086^{*}$ & 0.707 & 0.388 & 0.546 & 0.180 & 0.326 & 0.235 & 0.778 \\
\hline $\operatorname{Lexc}_{t-1}$ & & & -0.691 & 0.804 & & & $-0.967^{*}$ & 0.746 \\
\hline $\operatorname{Lexc}_{t-2}$ & & & 0.386 & 0.828 & & & & \\
\hline $\operatorname{Lexc}_{t-3}$ & & & 0.190 & 0.862 & & & & \\
\hline $\operatorname{Lexc}_{t-4}$ & & & -0.807 & 0.560 & & & & \\
\hline$R^{2}$ & 0.996 & & 0.990 & & 0.9056 & & 0.954 & \\
\hline \multicolumn{9}{|c|}{ Diagnostic } \\
\hline $\mathrm{J}-\mathrm{B}$ & 16.946 & 0.000 & 26.456 & 0.000 & 28.484 & 0.000 & 8.573 & 0.014 \\
\hline LM & 0.131 & 0.937 & 3.684 & 0.159 & 4.341 & 0.11 & 0.741 & 0.690 \\
\hline AR & 1.497 & 0.473 & 1.720 & 0.423 & 1.458 & 0.48 & 3.551 & 0.169 \\
\hline
\end{tabular}

Note: $* * * ; * * *$ are statistically significant at $\alpha=1 \%, 5 \%$ and $10 \%$. J-B is Jarque-Bera test, LM is a Lagrange Multiplier test, and ARCH is autoregressive conditional heteroskedasticity test

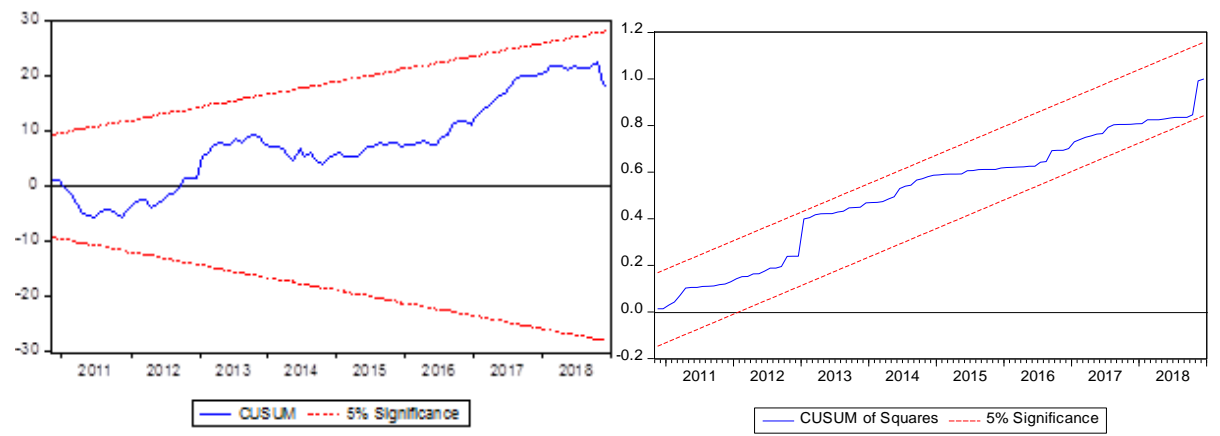

Figure 3. Stability test of Z-Score for IRB

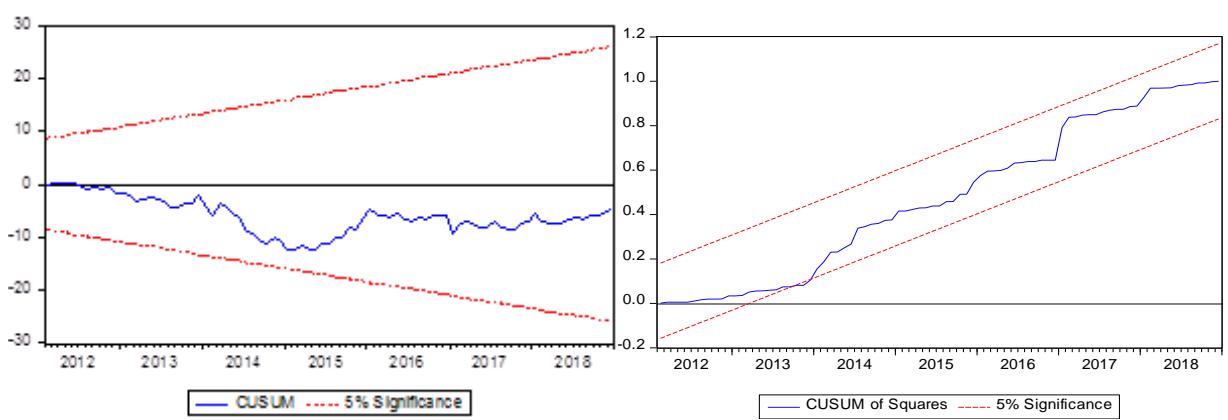

Figure 4. Stability test of Z-Score for CRB 

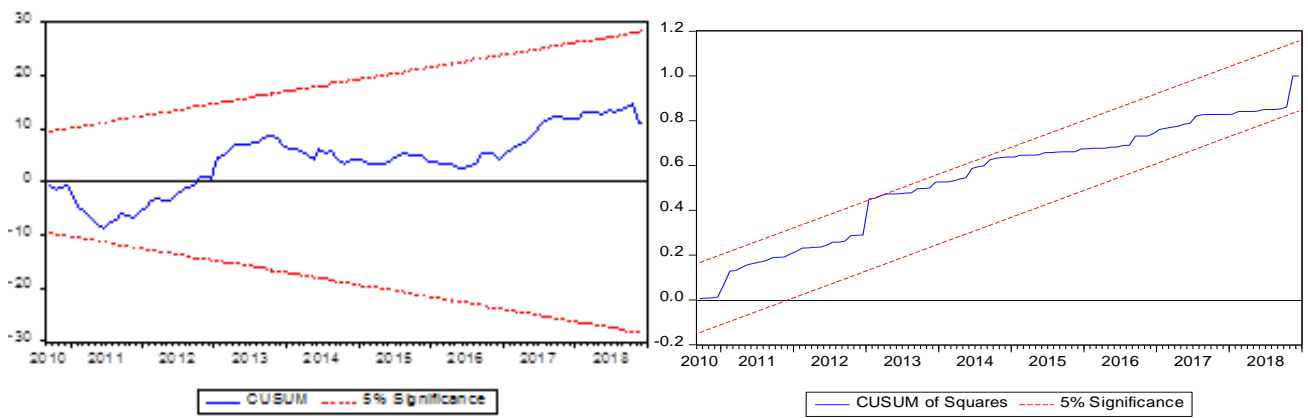

Figure 5. Stability test of ROA for CRB
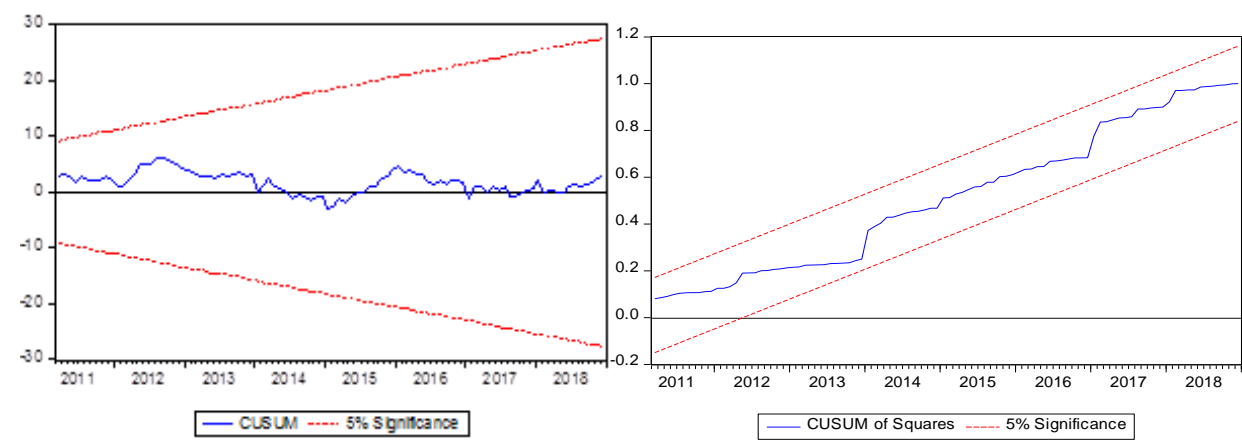

Figure 6. Stability test of ROA for CRB

The next step checks a cointegration employing the bound test to catch up on the long-run relationship between variables. The cointegration test results are exhibited in Table 4. The computed $\mathrm{F}$ values are 3.9472 and 2.8418 for IRB and 4.8930 and 3.6584 for CRB, respectively. With the exception for ROA IRB, these computed F value is greater than $\mathrm{I}(1)$ at $\alpha=1 \%$ so it can be summed up that cointegration between the dependent variable and independent variables is presence. It is not clear for ROA IRB because the value of computed F value is between I(0) and I(1) at $\alpha=10 \%$. Therefore, based on these results, this study can investigate the financial stability of IRB and $\mathrm{CRB}$ and their relations to all independent variables for not only short-run but also long-run conditions.

Table 5. The Bound Test

\begin{tabular}{llllrll}
\hline \multicolumn{1}{l}{ Computed F value } & & & \multicolumn{3}{c}{ Critical F value } \\
\hline Z-Score IRB & Z-Score CRB & ROA IRB & ROA CRB & \multicolumn{1}{c}{$\alpha$} & \multicolumn{1}{l}{ I $(0)$} & \multicolumn{1}{l}{ I(1) } \\
\hline $3.9472^{* * *}$ & $4.8930^{* * *}$ & 2.8418 & $3.6584^{* *}$ & $10 \%$ & 1.9200 & 2.8900 \\
\hline & & & $5 \%$ & 2.1700 & 3.2100 \\
\hline & & & $2.5 \%$ & 2.4300 & 3.5100 \\
\hline
\end{tabular}

Note: $* * * ; * * * *$ are statistically significant at $\alpha=1 \%, 5 \%$, and $10 \%$ based on the Bound Test of cointegration.

Table 6. Short run coefficient of financial stability

\begin{tabular}{|c|c|c|c|c|c|c|c|c|}
\hline & IRB & & CRB & & IRB & & CRB & \\
\hline & Coeff. & s.e & Coeff. & s.e & Coeff. & s.e & Coeff. & s.e \\
\hline$\Delta Y_{t-1}$ & $-0.082 * *$ & 0.037 & $0.142 * *$ & 0.084 & & & 0.067 & 0.087 \\
\hline$\Delta Y_{t-2}$ & & & $0.332 * * *$ & 0.085 & & & $0.096 * * *$ & 0.031 \\
\hline$\Delta Y_{t-3}$ & & & $0.175^{* *}$ & 0.081 & & & $-0.042 * *$ & 0.023 \\
\hline
\end{tabular}




\begin{tabular}{|c|c|c|c|c|c|c|c|c|}
\hline & IRB & & CRB & & IRB & & CRB & \\
\hline & Coeff. & s.e & Coeff. & s.e & Coeff. & s.e & Coeff. & s.e \\
\hline$\Delta Y_{t-4}$ & & & $-0.028^{*}$ & 0.018 & & & & \\
\hline$\Delta$ Lasset $_{t}$ & & & -0.119 & 0.254 & & & 0.169 & 0.318 \\
\hline $\operatorname{s}_{\text {Lasset }}{ }_{t-1}$ & & & 0.121 & 0.263 & & & $0.989 * * *$ & 0.344 \\
\hline$\Delta_{\text {Lasset }_{t-2}}$ & & & $-0.981 * * *$ & 0.251 & & & $-0.798 * *$ & 0.352 \\
\hline${ }_{\Delta \text { Lasset }_{t-3}}$ & & & $-0.543 * *$ & 0.259 & & & -0.289 & 0.333 \\
\hline$\Delta_{\text {Lasset }}{ }_{t-4}$ & $-5.338 * *$ & 2.434 & & & $-1.952^{*}$ & 1.219 & & \\
\hline$\Delta C A R_{t}$ & $2.480 * * *$ & 0.093 & $0.719 * * *$ & 0.012 & $0.130 * * *$ & 0.045 & & \\
\hline$\Delta C A R_{t-1}$ & & & $-0.115^{* *}$ & 0.064 & $-0.146^{* * *}$ & 0.052 & & \\
\hline$\Delta C A R_{t-2}$ & & & $-0.236^{* * *}$ & 0.062 & & & & \\
\hline$\Delta C A R_{t-3}$ & & & $-0.119 * *$ & 0.060 & & & & \\
\hline$\Delta C A R_{t-4}$ & & & $0.034^{* *}$ & 0.018 & & & & \\
\hline$\Delta C A R_{t-5}$ & & & $0.016^{*}$ & 0.010 & & & & \\
\hline$\Delta N P F_{t}$ & & & $0.072 * *$ & 0.033 & & & 0.044 & 0.047 \\
\hline$\Delta N P F_{t-1}$ & & & -0.012 & 0.036 & & & -0.058 & 0.051 \\
\hline$\overline{\Delta N P F_{t-2}}$ & & & 0.016 & 0.037 & & & $0.072 *$ & 0.049 \\
\hline$\Delta N P F_{t-3}$ & & & $-0.104 * * *$ & 0.035 & & & $-0.110 * *$ & 0.043 \\
\hline$\Delta I P I_{t}$ & 0.002 & 0.008 & & & 0.000 & 0.004 & & \\
\hline$\Delta I P I_{t-1}$ & $-0.063 * * *$ & 0.012 & & & $-0.019 * * *$ & 0.005 & & \\
\hline$\Delta I P I_{t-2}$ & $-0.051 * * *$ & 0.012 & & & $-0.013 * * *$ & 0.005 & & \\
\hline$\Delta I P I_{t-3}$ & $-0.044 * * *$ & 0.010 & & & $-0.012 * * *$ & 0.004 & & \\
\hline$\Delta I P I_{t-4}$ & $-0.016 * *$ & 0.008 & & & & & & \\
\hline$\Delta I P I_{t-5}$ & & & & & & & $-0.036^{* *}$ & 0.019 \\
\hline$\Delta C P I_{t}$ & & & 0.388 & 0.460 & & & 0.235 & 0.648 \\
\hline $\operatorname{Lexc}_{t-1}$ & & & 0.231 & 0.491 & & & & \\
\hline $\operatorname{Lexc}_{t-2}$ & & & 0.617 & 0.508 & & & & \\
\hline $\operatorname{Lexc}_{t-3}$ & & & $0.807 * *$ & 0.482 & & & & \\
\hline$E C_{t-1}$ & $-0.249 * * *$ & 0.040 & $-0.491 * * *$ & 0.071 & $-0.239 * * *$ & 0.045 & $-0.381 * * *$ & 0.064 \\
\hline$R^{2}$ & 0.884 & & 0.992 & & 0.270 & & 0.544 & \\
\hline
\end{tabular}

Note: $* * * ; * ; *$ are statistically significant at $\alpha=1 \%, 5 \%$ and $10 \%$ respectively. Y is Z-score or ROA.

This study displays the short-run conditions in Table 5. All the lag error $\left(\mathrm{EC}_{\mathrm{t}-1}\right)$, as an error correction variable in the ARDL model, is a negative sign and statistically significant at $\alpha=1 \%$ for both IRB as well as CRB. The short-run ARDL model, therefore, is valid to investigate the short-run condition of financial stability and profitability. Variables affecting the financial stability of IRB are the lag of Z-Score, Asset, CAR, and IPI. By contrast, the CRB's financial stability is influenced by the lag of Z-Score, Asset, CAR, NPF, and exchange rate. The profitability of IRB depends on assets, CAR, and IPI. However, the profitability of CBR is affected by the lag of ROA, asset, NPF, IPI as well as the exchange rate.

In general, it can be concluded that both the bank Characteristics and macro variables affect the short condition of financial stability and profitability of both banks. However, the error term variable (ECt-1) of IRB is lower than those of CBR. For example, the value of error correction for Z-Score is -0.249 for IRB and -0.491 for CRB. The lower error correction of IRB indicates that if there is a disequilibrium condition, the adjustment process leads to the balanced 
condition of the IRB at a slower time compared to its counterpart. The slow adjustment process originates from the types of IRB financing that are less flexible because each financing contract must be in accordance with Islamic principles and get approval from the Sharia Supervisory Board (Hussein, 2010; Waemustafa and Sukri, 2016).

Next is the main theme analysis associated with the long-term condition of the ARDL model. The long-term coefficients are presented in Table 6 . The variables that affect the Z-Score as a proxy of IRB's financial stability are CAR, IPI, CPI, and exchange rates. The CAR affects positively the Z-score. These results are similar to previous empirical studies such as Čihák and Hesse (2010) and Ghenimi et al., 2017). An adequate CAR makes better protection against the IRB's bankruptcy.

Table 7. Long run coefficient of financial stability and profitability

\begin{tabular}{|c|c|c|c|c|c|c|c|c|}
\hline & \multicolumn{2}{|l|}{ Z-Score IRB } & \multicolumn{2}{|c|}{ Z-Score CRB } & \multicolumn{2}{|l|}{ ROA IRB } & \multicolumn{2}{|l|}{ ROA CRB } \\
\hline & Coeff. & s.e & Coeff. & s. e & Coeff. & s. e & Coeff. & s. e \\
\hline$C$ & -85.650 & 70.146 & 11.404 & 8.682 & $-71.111 * *$ & 33.708 & $21.889^{*}$ & 13.862 \\
\hline Lasset $_{t}$ & 4.344 & 5.140 & 0.224 & 0.739 & $4.974 * *$ & 2.353 & -0.016 & 1.221 \\
\hline $\operatorname{gfin}_{t}$ & 0.668 & 16.212 & 1.740 & 3.028 & 5.630 & 7.883 & $9.037 * *$ & 5.029 \\
\hline$\overline{C A R_{t}}$ & $2.622 * * *$ & 0.434 & $0.758 * * *$ & 0.064 & $0.457^{* * *}$ & 0.196 & 0.039 & 0.058 \\
\hline$N P F_{t}$ & 0.151 & 0.256 & $-0.109 * *$ & 0.046 & 0.102 & 0.121 & $-0.183^{* *}$ & 0.083 \\
\hline$I P I_{t}$ & $0.227 * * *$ & 0.096 & $0.018 * * *$ & 0.006 & $0.060 *$ & 0.041 & $0.022 * *$ & 0.010 \\
\hline$C P I_{t}$ & $-0.454 * * *$ & 0.154 & $-0.033 * *$ & 0.021 & $-0.230 * * *$ & 0.075 & -0.025 & 0.035 \\
\hline $\operatorname{Lexc}_{t}$ & $4.361 *$ & 3.150 & $-1.088 * * *$ & 0.351 & 0.753 & 1.416 & $-1.919 * * *$ & 0.627 \\
\hline
\end{tabular}

Note: $* * * * * ; *$ are statistically significant at $\alpha=1 \%, 5 \%$ and $10 \%$ respectively

Based on these findings, the adequacy of the CAR is a safety valve and it ensures IRB's stability. IRB, therefore, must preserve a minimum capital to assure sufficient funds as unexpected losses and a negative shock hits it. Macroeconomic variables such as output growth and exchange rate have a positive impact while inflation has a negative impact on the Z-score. This research is in line with the previous studies such as Rahim and Zakaria (2013); Fayed (2013); Trad et al. (2017). Good macroeconomic conditions such as high economic growth and low inflation encourage an increase in the IRB's profitability to reduce the IRB's failure and increase the IRB's stability. For CRB, CAR has a positive effect and NFP has a negative effect on Z-score as expected. Output has a positive effect while inflation and exchange rates negatively affect the Z-score. More interestingly, the coefficients of IRB such as CAR, IPI, and CPI are higher for those of CRB. That is, even though the IRB is less risky because of the higher Z-score, the stability of the IRB is very vulnerable to changes in bank characteristics as well as macroeconomic variables.

The next analysis is the profitability of banks. IRB's profits are influenced by assets, CAR, IPI, and CPI. Bank characteristic variables comprising assets and CAR have a positive effect on IRB's profits. However, the impact of assets is more dominant compared to CAR for banking profits. These findings confirm the previous empirical researches (Muda et al., 2013; Rashid and Jabeen, 2016). The high asset means the greater the IRB size so that it causes higher profitability. Similarly, the stronger the bank's capital as measured by CAR, the higher the ability of IRB to increase its profits. IPI affects positively and CPI affects negatively on the profitability of the IRB. This finding shows that macroeconomic stability promotes IRB profits. These findings are in line with the preceding researches (Choong et al., 2012; Warninda, 2014; Trad et al., 2017). The CBR's profitability is affected by the growth of financing (gfin), NPF, IPI, and exchange rates. However, the IRB regression coefficient for output (IPI) is higher than that of CRB. It implies that the IRB's profit is very sensitive to changes in macroeconomic variables compared to CRB's profit. The main reason is that IRB is a new player in providing funds for micro, small, and medium enterprises in Indonesia.

\section{Conclusion}

This study aims to analyze whether the financial performance of IRB with the types of PLS and non-PLS system contracts is better than CRB as its competitors. The financial performance is measured by financial stability and profitability. Financial stability is computed using Z-Score while ROA represents profitability. The regression 
analysis used is the ARDL model as a dynamic time series model using monthly data. Independent variables consist of bank characteristics as well as macroeconomic variables.

There are several important results from this study. First, based on the Z-Score, this study shows that the IRB"s financial stability is better than the CRB. This result implies that IRB has a lower risk of failure compared to CRB, even though the value of NPF is higher compared to CRB. Second, the IRB's profit is lower but more stable than the CRB's profit. Third, bank size and capital are the key indicators that strongly affect IRB's financial stability and profitability. However, the financial stability and profitability of IRB are more susceptible to changes in both the characteristics of Islamic banks and macroeconomic variables. There are several important implications of these findings that can be applied for IRB. First, IRB can be alternative financing based on the principles of PLS and non-PLS rather than based on fixed costs for micro, small, and medium enterprises in Indonesia. Second, the key indicators for maintaining financial stability and the profitability of IRB are the size of banks and equity. These results imply that IRB must be able to increase assets and equity to compete with CRB.

\section{Acknowledgment}

This research was fully funded by the Indonesian Ministry of Research, Technology, and Higher Education, (Grant number:025/ST-DirDPPM/70/DPPM/PEN.DASAR UPT-KEMENRISTEKDIKTI/III/2019).

\section{References}

Abdulle, M. Y., \& Kassim, S. H. (2012). Impact of global financial crisis on the performance of islamic and conventional banks: empirical evidence from Malaysia. Journal of Islamic Economics, Banking and Finance, $8(4), 9-20$.

Abedifar, P., Molyneux, P., \& Tarazi, A. (2013). Risk in Islamic banking. Review of Finance, 17(6), 2035-2096. https://doi.org/10.1093/rof/rfs041

Alaro, A. A., \& Hakeem, M. (2011). Financial engineering and financial stability: The role of Islamic financial system. Journal of Islamic Economics , Banking and Finance, 7(1), 25-38.

Alqahtani, F., Mayes, D. G., \& Brown, K. (2016, January). Economic turmoil and Islamic banking: Evidence from the Gulf Cooperation Council. Pacific Basin Finance Journal, 39, 44-56. https://doi.org/10.1016/j.pacfin.2016.05.017

Azmat, S., Skully, M., \& Brown, K. (2015). Can Islamic banking ever become Islamic?. Pacific Basin Finance Journal, 34, 253-272. https://doi.org/10.1016/j.pacfin.2015.03.001

Baele, L., Farooq, M., \& Ongena, S. (2014). Of religion and redemption: Evidence from default on Islamic loans. Journal of Banking and Finance, 44(1), 141-159. https://doi.org/10.1016/j.jbankfin.2014.03.005

Beck, T., Demirgüç-Kunt, A., \& Merrouche, O. (2013). Islamic vs. conventional banking: Business model, efficiency and stability. Journal of Banking and Finance, 37(2), 433-447. https://doi.org/10.1016/j.jbankfin.2012.09.016

Choong, Y. V., Thim, C. K., \& Kyzy, B. T. (2012). Performance of Islamic commercial banks in Malaysia: An empirical study. Journal of Islamic Economics, Banking and Finance, 8(2), 67-80.

Čihák, M., \& Hesse, H. (2010). Islamic banks and financial stability: An empirical analysis. Journal of Financial Services Research, 38(2), 95-113. https://doi.org/10.1007/s10693-010-0089-0

Fayed, M. E. (2013). Comparative performance study of conventional and Islamic banking in Egypt. Journal of Applied Finance \& Banking, 3(2), 1-14.

Ghenimi, A., Chaibi, H., \& Omri, M. A. B. (2017). The effects of liquidity risk and credit risk on bank stability: Evidence from the MENA region. Borsa Istanbul Review, 17(4), 238-248. https://doi.org/10.1016/j.bir.2017.05.002

Hassan, M. K., Khan, A., \& Paltrinieri, A. (2019). Liquidity risk, credit risk and stability in Islamic and conventional banks. Research in International Business and Finance, 48, 17-31. https://doi.org/10.1016/j.ribaf.2018.10.006

Hussein, K. (2010). Bank-level stability factors and consumer confidence-A comparative study of Islamic and conventional banks product mix. Journal of Financial Services Marketing, 15(3), 259-270. https://doi.org/10.1057/fsm.2010.21

Hussien, M., Alam, M. M., \& Murad, M. W. (2019). The performance of Islamic banks during the 2008 Global Financial Crisis: Evidence from Gulf Cooperation Council Countries. Journal of Islamic Accounting and 
Business Research, 10(3), 407-420. https://doi.org/10.2139/ssrn.2517359

Ibrahim, M. H., \& Rizvi, S. A. R. (2017). Do we need bigger Islamic banks? An assessment of bank stability. Journal of Multinational Financial Management, 40, 77-91. https://doi.org/10.1016/j.mulfin.2017.05.002

Kabir, M. N., \& Worthington, A. C. (2017). The 'competition-stability/fragility' nexus: A comparative analysis of Islamic and conventional banks. International Review of Financial Analysis, 50, 111-128. https://doi.org/10.1016/j.irfa.2017.02.006

Kabir, M. N., Worthington, A., \& Gupta, R. (2015). Comparative credit risk in Islamic and conventional bank. Pacific Basin Finance Journal, 34, 327-353. https://doi.org/10.1016/j.pacfin.2015.06.001

Lassoued, M. (2018). Comparative study on credit risk in Islamic banking institutions: The case of Malaysia. Quarterly Review of Economics and Finance, 70, 267-278. https://doi.org/10.1016/j.qref.2018.05.009

Masood, O., \& Ashraf, M. (2012). Bank-specific and macroeconomic profitability determinants of Islamic banks: The case of different countries. Qualitative Research in Financial Markets, 4(2-3), 255-268. https://doi.org/10.1108/17554171211252565

Miah, M. D., \& Uddin, H. (2017). Efficiency and stability: A comparative study between islamic and conventional banks in GCC countries. Future Business Journal, 3(2), 172-185. https://doi.org/10.1016/j.fbj.2017.11.001

Miniaoui, H., \& Gohou, G. (2013). Did Islamic Banking Perform Better during the Financial Crisis?: Evidence from the UAE. Journal of Islamic Economics, Banking and Finance, 9(2), 115-130. https://doi.org/10.12816/0001605

Mirza, N., Rahat, B., \& Reddy, K. (2015). Business dynamics, efficiency, asset quality and stability: The case of financial intermediaries in Pakistan. Economic Modelling, 46, 358-363. https://doi.org/10.1016/j.econmod.2015.02.006

Muda, M., Shaharuddin, A., \& Embaya, A. (2013). Comparative analysis of profitability determinants of domestic and foreign Islamic banks in Malaysia. International Journal of Economics and Financial Issues, 3(3), 559-569.

Parashar, S. P., \& Venkatesh, J. (2010). How did Islamic banks do during global financial crisis?. Banks and Bank Systems, 5(4), 54-62.

Pesaran, M. H., Shin, Y., \& Smith, R. J. (2001). Bounds testing approaches to the analysis of level relationships. Journal of Applied Econometrics, 16(3), 289-326. https://doi.org/10.1002/jae.616

Rahim, S. R. M., \& Zakaria, R. H. (2013). Comparison on stability between Islamic and conventional banks in Malaysia. Journal of Islamic Economics, Banking and Finance, 9(3), 131-149. https://doi.org/10.12816/0001618

Rashid, A., \& Jabeen, S. (2016). Analyzing performance determinants: Conventional versus Islamic Banks in Pakistan. Borsa Istanbul Review, 16(2). https://doi.org/10.1016/j.bir.2016.03.002

Srairi, S. (2019). Transparency and bank risk-taking in GCC Islamic banking. Borsa Istanbul Review, 19, S64-S74. https://doi.org/10.1016/j.bir.2019.02.001

Sutrisno, \& Widarjono, A. (2018). Maqasid sharia index, banking risk and performance cases in Indonesian Islamic banks. Asian Economic and Financial Review, 8(9), 1175-1184. https://doi.org/10.18488/journal.aefr.2018.89.1175.1184

Trad, N., Trabelsi, M. A., \& Goux, J. F. (2017). Risk and profitability of Islamic banks: A religious deception or an alternative solution?. European Research on Management and Business Economics, 23(1), 40-45. https://doi.org/10.1016/j.iedeen.2016.09.001

Trinugroho, I., Risfandy, T., \& Ariefianto, M. D. (2018). Competition, diversification, and bank margins: Evidence from Indonesian Islamic rural banks. Borsa Istanbul Review, 18(4), 349-358. https://doi.org/10.1016/j.bir.2018.07.006

Trinugroho, I., Risfandy, T., Ariefianto, M. D., Prabowo, M. A., Purnomo, H., \& Purwaningsih, Y. (2017). Does religiosity matter for Islamic banks' performance? Evidence from Indonesia. International Journal of Economics and Management, 11(2), 419-435.

Waemustafa, W., \& Sukri, S. (2016). Systematic and unsystematic risk determinants of liquidity risk between Islamic and Conventional Banks. International Journal of Economics and Financial Issues, 6(4), 1321-1327. 
Warninda, T. D. (2014). Islamic Rural Bank Profitability: Evidence from Indonesia. Journal of Islamic Economics, Banking and Finance, 3, 109-122.

Widarjono, A., Anto, M. B. H., \& Fakhrunnas, F. (2020). Financing Risk in Indonesian Islamic Rural Banks : Do Financing Products Matter?. The Journal of Asian Finance, Economics and Business, 7(9), 305-314. https://doi.org/10.13106/jafeb.2020.vol7.no9.305

Widarjono, A., Mifrahi, M. N., \& Perdana, A. R. A. (2020). Determinants of Indonesian Islamic rural banks' profitability: Collusive or non- collusive behavior?. The Journal of Asian Finance, Economics and Business, 7(11), 657-668. https://doi.org/10.13106/jafeb.2020.vol7.no11.657

Zins, A., \& Weill, L. (2017, August). Islamic banking and risk: The impact of Basel II. Economic Modelling, 64(2016), 626-637. https://doi.org/10.1016/j.econmod.2017.05.001

\section{Copyrights}

Copyright for this article is retained by the author(s), with first publication rights granted to the journal.

This is an open-access article distributed under the terms and conditions of the Creative Commons Attribution license (http://creativecommons.org/licenses/by/4.0/). 